\title{
Methods for the improvement of the water supply in the Chaco of Paraguay
}

Federal Institute for Geosciences and Natural Resources (BGR), P. O Box 510153, 30631 Hannover, Germany.

The Chaco of Paraguay, occupying two thirds of the territory of the Republic of Paraguay, is a region with an extreme subtropical climate, a lack of a modern infrastructure and scarce potable water resources. An ongoing bilateral co-operation project between Germany and Paraguay has the objective to improving the water supply conditions in the area. This aim is achieved through parallel project activities: (a) Investigation of groundwater conditions jointly with the Direccion de Recursos Hidricos, at the same time strengthening the operational capacity of this institution. (b) Development of methods for sustained utilisation of the scarce fresh water resources and for the protection of groundwater against contamination. (c) Construction of water supply systems applying a simple technology for rural settlements of the native Indian population and the campesinos.

\section{Introduction}

The Chaco $\left(240000 \mathrm{~km}^{2}\right)$ occupies approximately two thirds of the territory of the Republic of Paraguay, but only 2 percent of the population live in this region (Figure 1). The extreme subtropical climate, the lack of a modern infrastructure and above all the scarcity of potable water have so far prevented a large scale colonisation of the area. At present the country experiences a high population growth, which the traditional settlement areas in the east of the Rio Paraguay cannot support. The development and colonisation of the Chaco is therefore the declared objective of the Government of Paraguay. Given the fragility of the ecosystem of the Chaco much effort has been made to achieving a sustainable development of the area.

The limited availability of drinking water is a principal constraint for the establishment of settlements and for cattle ranching industry. The Governments of Germany and Paragua, under a bilateral agreement of co-operation, initiated a project in 1992 with the objective to improving the accessibility of good quality drinking water in urban and rural areas of the Chaco. To achieve its goals, the project has pursued the philosophy of working at the local level with local institutions, and in direct contact with water consumers.

The project is carried out by the Federal Institute for Geosciences and Natural Resources (BGR), the German partner, and the Dirección de Recursos Hídricos (DRH), residing in Filadelfia in the Central Chaco, the Paraguayan institution in charge of water resources development in the Chaco. It is directed at three target groups with differing objectives: (a) Dirección de Recursos Hídricos: training of technical and scientific personnel, introduction of modern methods for the exploration and development of groundwater resources combined with the installation of the necessary techni- cal equipment; (b) the population of the urban centres: development of methods for improved underground storage of fresh groundwater, and protection of fresh groundwater resources against contamination; (c) the population of the rural areas i.e. campesinos, indigenous Indians: construction of water supply systems with the participation of the village communities.

\section{Strengthening of the local water development institution}

Project activities centre on the Dirección de Recursos Hídricos (DRH). Due to the lack of large surface water bodies, groundwater is of great importance for the water supply. Much investigative work was done by the DRH in the 1970s and 1980s with the support of the UNDP, but knowledge of the hydrogeological conditions has still been fragmentary. The project therefore combines the investigation of groundwater resources with the training of personnel. Starting with university leavers, the German experts introduce young geologists to the practical hydrogeological work, whilst the theoretical base knowledge of hydrogeology is acquired in university master's study programmes after completion of all field work. Important for the long term working capability of the DRH is the fact that all trained personnel retain permanent posts with the DRH, thus the

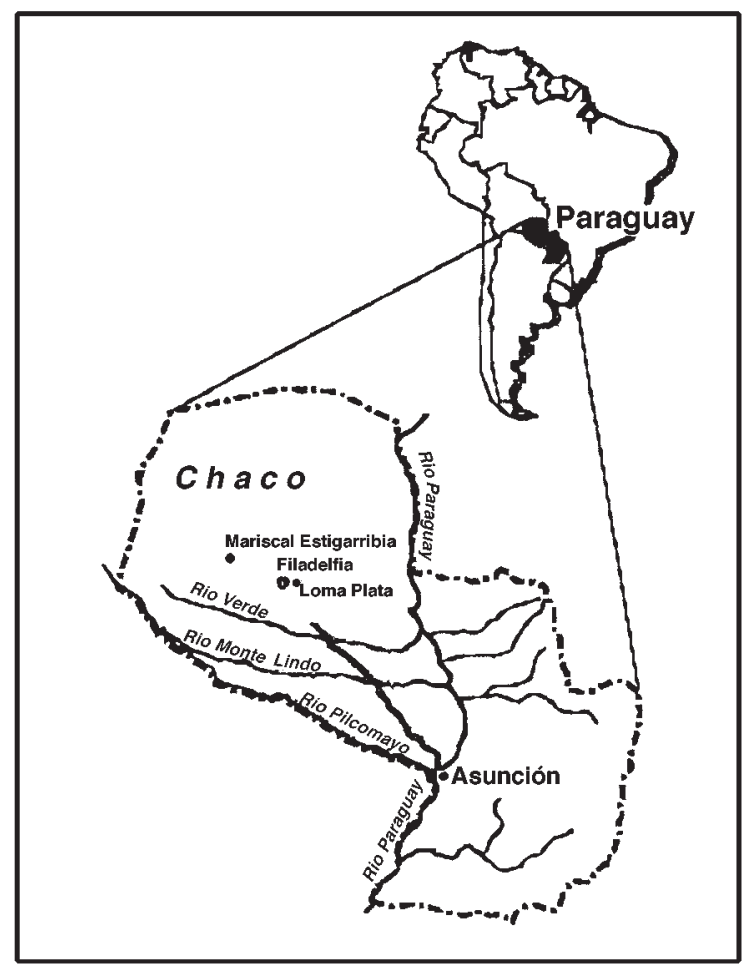

Figure 1 Locaton of the Chaco in Paraguay. 
acquired knowledge remains and can be reproduced within the region of the Chaco.

To enable the DRH to perform standard hydrogeological investigations in the Chaco, the project has purchased drilling equipment and hydrogeological field instruments, equipped a water quality laboratory and installed computer hardware and software. The DRH not only carries out exploration work with drilling rigs; it constructs water wells for farms and settlements, thus generating an income that is reinvested in the maintenance of the equipment and offices and allows a certain degree of independence from the budget of the central government. The water quality laboratory, the only one in western Paraguay, is often consulted by farmers and town engineers. The project has succeeded in establishing the DRH as an institution that offers services to the region. In turn, it receives the political support of the local and provincial authorities which is indispensable for its future existence.

\section{Investigation of the groundwater resources}

The main objective of the hydrogeological investigations carried out by the project is to improve the knowledge of groundwater conditions in the central part of the Chaco, where three Mennonite colonies have led to a population concentration (Figure 1). A brief overview explains the hydrological conditions in the area which govern the availability of drinking water.

The annual mean precipitation is between 800 and $900 \mathrm{~mm}$. In individual years up to $1,600 \mathrm{~mm}$ have been recorded. Most of the rain falls during the months from November to March, when temperatures and plant growth are at their peak, and hence evapotranspiration is at its highest, so that a major portion of the rainwater is directly evaporated. To develop storage of rainwater for the annual long dry period is the essential task, if an uninterrupted water supply is to be guaranteed. Three methods are in use and their technology has been further developed by the project.

(a) Rainwater harvesting: rainwater is being collected from house roofs and drained into underground cisterns from where it is pumped into a raised water tank. Water then is piped into the house. A cistern capacity of 25,000 litres per person is recommended (Keller, 1995). Provided drain pipes and cisterns are kept clean a good quality water supply is obtained. Of course, this water collection system requires a fairly large and rigid roof area plus electricity for the water lifting pump. Therefore, it can only be operated at town or farm houses. The poor population of the rural settlements living in grass or wood shingle covered huts cannot use this technology.

(b) Water wells: in the area between the towns of Mariscal Estigarribia in the west and Loma Plata in the east, groundwater occurs at shallow depths (3 to $13 \mathrm{~m}$ below ground surface) in fine-grained sands. It is generally saline with the exception of a few specific localities where fresh groundwater lenses are encountered. The groundwater is recharged by the annual rains (Echeverria, 1989, Godoy, 1990). The project has developed methods for the detection of such fresh water lenses. These include field surveys of soils, vegetation and drainage (Von Hoyer \& Godoy, 1996), combined with the interpretation of air photos and satellite images and hand-drilled investigation holes (Mollat \& Larozza, 1997). The lenses are generally small and thus sufficient only for the supply of homesteads and small settlements. Over-pumping leads to the intrusion of the surrounding saline water.

The natural process of rainwater infiltration in a morphological depression underlain by sands with the subsequent formation of a fresh water lens, floating on the surrounding saline groundwater, can be reproduced artificially. In a morphological depression, which receives the surface runoff of a larger catchment area, an open air reservoir, a so-called tajamar, is excavated by earth-moving equipment. The dimensions of the reservoir are determined by the lateral extent of the sandy formation, the depth to the groundwater table and the slope stability of the reservoir walls. Storage volumes normally are in the range of 10,000 to $20,000 \mathrm{~m}^{3}$. In urban areas the runoff from a network of street ditches may be channelled into the tajamares. In the towns of Filadelfia, Loma Plata and Neu-Halbstadt a system of several infiltration tajamares with production wells supply the commercial centre, small industrial plants, schools, hospitals and hotels. The project studied the artificial recharge process in model cases and defined the parameters which determine the size of the fresh water body underneath a tajamar as well as the quantity of extractable fresh water (Junker, 1996).

(c) Surface water storage: the extensive areas of the Central Chaco are covered by loams and sandy clays and the technique of artificial infiltration of rainwater cannot be practised. These are also the areas where only saline groundwater is encountered. Here tajamares are excavated in the low permeable formation and surface water is stored during dry months. This method of water supply is the least favourable: firstly, because of the high water loss due to evaporation (1,500 $\mathrm{mm}$ per year), and secondly, because of the poor water quality. The tajamar water carries a high content of clay and silt in suspension, together with a multitude of micro-organisms, many harmful to man. Intestinal infectious diseases are abundant.

This observation is also true for the water found in lagoons and water holes. Most of the indigenous Indian population and the poor campesinos living in remote areas rely however exclusively on such unhygienic water resources.

\section{Direct measures of providing drinking water for the poor rural population in the Chaco}

In view of the inadequate water supply of the rural population in the Chaco the project embarked on the construction of water supply systems in small settlements in 1994. Depending on the local water resources conditions, one or a combination of the above described water supply techniques was implemented.

From the onset the project pursued the aim that the water supply systems that were to be constructed should be operated and maintained by the village communities. Consequently the technology used had to be simple and adapted to the local supply conditions and the communities had to be involved from the planning stage right through to the construction. The baseline adopted for the supply standards was: a guaranteed year-round water supply if possible from groundwater and water points in form of cisterns with hand pumps at a maximum distance of $400 \mathrm{~m}$ from each household.

The project reacts to applications from village communities, and the application has to state the input of the community. In the majority of cases the contribution is labour. In the planning phase the village community has to form a water committee which identifies the water needs and at the same time names the persons responsible for the organisation and execution of work. The project staff and the water committee plan the supply network and water points. Often this has to be repeated until the final layout is agreed upon. During the construction phase the project supplies the building material and necessary tools free of cost. The building material is delivered not in bulk, but as work progresses, in order to avoid waste and to call in the work contribution from the villagers. The project staff teach the workers various mechanical skills needed and make sure that the work is carried out as planned. Running the water project in this manner means of course that the community dictates the speed of the work; it guarantees however that the village people carry the project all the way. This is essential for future operation and maintenance of the installations.

Technically modified wind pumps are used to lift water from wells and tajamares and pump the water into the mains under low pressure. They yield between 9,000 and 20,000 liters of water on a windy day, depending on the type of pump construction and the length of pipeline. Flexible PVC-water pipe $37 \mathrm{~mm}$ in diameter car- 
ries the water to underground cisterns, where the flow is regulated by float and valve. From here the water is lifted by hand pumps. The cisterns have a storage capacity between 5,000 and 8,000 litres and serve as reservoirs, when there is no wind. Where muddy tajamar water is the only supply, slow-flow-gravity sand filters, built next to the cisterns, achieve a part reduction of the silt load and germs and improve the taste of the water.

From 1994 until 1998 the project constructed water supply systems in 71 villages with a total of approximately 26,000 inhabitants. Construction costs, not counting the labour input of the village community, were between US\$17,000 (well water supply) and US\$19,000 (tajamar water supply) for a typical village of 60 houses with 400 inhabitants.

Technical staff of the DRH have been trained to carry out maintenance services that require the facilities of a mechanical work shop. Thus the village people can call on these services when major repairs become necessary. To secure the financial means for the maintenance work, agreements have been signed by the provincial administrations in the Chaco and the DRH, according to which the provinces remunerate the DRH for work performed in the communities.

\section{Conclusions}

The joint German-Paraguayan project, in the underdeveloped Chaco region, is an example for the direct application of scientific knowledge for the improvement of living conditions in very poor rural settlements. An all-year-round supply of good quality drinking water is the prerequisite for an improvement of the health status of the native Indian population and the Paraguayan settlers (campesinos). Despite a fairly high annual rainfall, water supply conditions are however unfavourable due to high evaporation losses, the lack of perennial rivers and lakes and the high salinity of the shallow groundwater. The results of hydrogeological investigations are used to detect existing small fresh groundwater lenses and develop these resources for the village water supply. Local, well-established, simple technology is employed for the construction of the supply systems and the pumping of the water. The practical involvement of the village communities in the planning and construction of the water supply is essential to the long-term operation and maintenance of the installations.

\section{References}

Echeverria, S. et al. (1989), Calidad química de las aguas subterr·neas del Chaco Paraguayo para consumo humano, agrícola y ganadero. - Rec. Nat., Geol. Hídrol., Agua Subt. Chaco Parag.: Publ. Dpto. Abast. Agua para el Chaco, S. 57 - 69, 4 Abb, 2 Taf.; DRH, Filadelfia, Paraguay.
Godoy, E.V. (1990), Caracteristicas hidrogeológicas e hídroquímicas de la region oeste del Chaco Paraguayo: Dpto. Abast. Agua para el Chaco, 107 S., 27 Abb., 7 Taf.; DRH, Filadelfia, Paraguay.

Junker, M. (1996), Determinación de las caracterÌsticas hidrogeológicas y evaluación de la recarga de agua subterránea en el rea del Tajamar Serenidad, Filadelfia: Info. Téc. No. 13, Coop. Hidrol. Parag. - Alem., 57 S, 33 Abb., 3 Taf.; BGR/DRH, Filadelfia, Paraguay.

Keller, S. (1995), Posibilidades de desarollo del Chaco Paraguayo por el control del consumo del agua subterránea y el aprovechamiento de las precipitaciones: Info. Téc. No. 14, Coop. Hidrol. Parag. - Alem., 25 S., 8 Abb.; BGR/DRH, Filadelfia, Paraguay.

Mollat, H. \& Larroza, F. (1997), Los sensores remotos aplicados a la busqueda de agua subterránea somera en el Chaco Central Paraguayo: Info. Téc. No. 22, Coop. Hidrol. Parag. - Alem., 24 S., 3 Abb., 1 Taf. BGR/DRH, Filadelfia, Paraguay.

Von Hoyer, M. \& Godoy, E.V. (1996), Metodos para la localización de lentes de agua dulce en el Chaco Central - Paraguay: Mem. XII Congr. Geol. de Bolivia, Tom. I, S. 309 - 320; Soc. Geol. Bol.,Tarija.

\begin{abstract}
Michael von Hoyer studied geology and hydrogeology at the university of Tübingen, Germany. From 1971 to 1975, he worked as a hydrogeologist in South Africa and the Middle East in the field of groundwater exploration and development. He joined the BGR in 1976 and has been the leader of groundwater projects in the semiarid and arid zones of Africa and South America. His interests are directed towards the study of natural and artificial groundwater recharge, groundwater protection and water legislation.
\end{abstract}

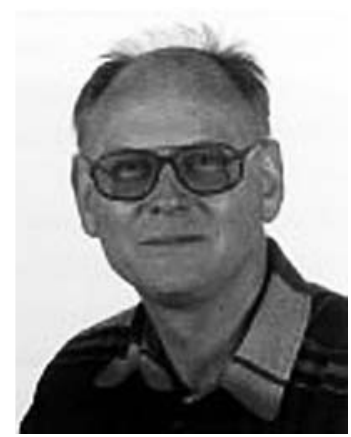

Eugenio Godoy V. received his master's degree in hydrogeology in 1989 from the University of Pernambuco, Brazil. Born in the remote Chaco of Paraguay he spent all his professional life in the investigation of the groundwater resources of this region, with the aim of improving the water supply and living conditions of the Chaqueños. In 1992 he became the Director of the Dirección de Recursos Hidricos, the central institution for water resources research and development in the Chaco and his great vision and professional talent transformed it into a capable groundwater investigation agency. Professionally known beyond Paraguay, he was co-author of the Hydrogeological Map of South America (1996). His tragic death in 1997 was a great loss to his colleagues and Paraguay. 